\title{
Reporte de influenza canina en Costa Rica
}

\author{
Martha Piche ${ }^{1}$, Alejandro Alfaro², Juan A. Morales², Pablo Murcia³, Carlos Jiménez $\bowtie$ \\ 1 Lab. de Virología, PIET, Escuela de Medicina Veterinaria, Universidad Nacional. \\ 2 Lab. de Patología, Escuela de Medicina Veterinaria, Universidad Nacional. \\ 3 Centre for Virus Research, MRC-University of Glasgow, Scotland.
}

Influenza canina causada por H3N8 fue descrita en 2004 en los Estados Unidos en Greyhounds. El agente etiológico es un mutante del virus de la influenza equina, H3N8. Posteriormente se describieron casos de influenza canina en Corea del Sur y China causados por un virus H3N2 de origen aviar; este virus causó brotes severos en Miami en el 2015. Las infecciones con influenza virus H3 en perros pueden ser subclínicas, con cuadros clínicos moderados o bien pueden evolucionar con cuadros severos de neumonía hemorrágica. El objetivo del presente reporte es describir la presentación de casos de influenza canina en Costa Rica en el período comprendido entre el 2012 y el 2016.

En total se estudiaron seis casos de caninos con enfermedad respiratoria aguda compatibles con infecciones con influenza virus H3. Para cada caso se recopiló la anamnesis, evolución y signos de los animales. En un caso se dispuso de hisopados nasales y conjuntivales del paciente vivo, en tanto que seis canes fallecidos fueron analizados mediante técnicas convencionales de necropsia, descripción de los hallazgos anatomopatológicos, estudio histopatológico (H\&E) e inmunohistoquímica con anticuerpos policlonales anti NP y anticuerpos monoclonales anti H3-canina. Para el estudio virológico se realizó aislamiento viral en huevos embrionados y células MDCK, PCR genérico de influenza virus A (gen de proteína de Matriz) y PCR específico para el gen H3.

El paciente vivo mostraba conjuntivitis y rinitis purulenta, en tanto que los animales fallecidos mostraron disnea, taquipnea, taquicardia y muerte. Los hallazgos anatomopatológicos revelaron pulmones con mayor consistencia y firmeza, color rojo oscuro y hemorragias pleurales multifocales; tráquea y bronquios con edema espumoso; meninges con edema y congestión venosa. Histopatológicamente se observó en el nivel de pulmones: congestión, hiperemia, severo edema bronquioalveolar y hemorragias alveolares, infiltrado inflamatorio mononuclear (linfocitos e histiocitos); en bronquios y bronquiolos se observó pared con infiltrado de linfocitos e hiperemia. La inmunohistoquímica de tejido pulmonar reveló amplia presencia de antígeno viral en epitelio respiratorio y tejido pulmonar. Los resultados de $\mathrm{PCR}$, tanto genérico como específico de $\mathrm{H} 3$, fueron positivos, tanto en tejidos analizados como en los aislamientos realizados en células MDCK y huevos embrionados.

Los hallazgos del presente reporte demuestran por primera vez la presentación de infecciones y casos clínicos con influenza virus $\mathrm{H} 3$ en perros de Costa Rica, lo cual obliga a considerar esta etiología dentro del diagnóstico diferencial de cuadros respiratorios en caninos.

$凶$ Autor para correspondencia Carlos Jiménez: carlos.jimenez.sanchez@una.cr / cajisan@yahoo.com 